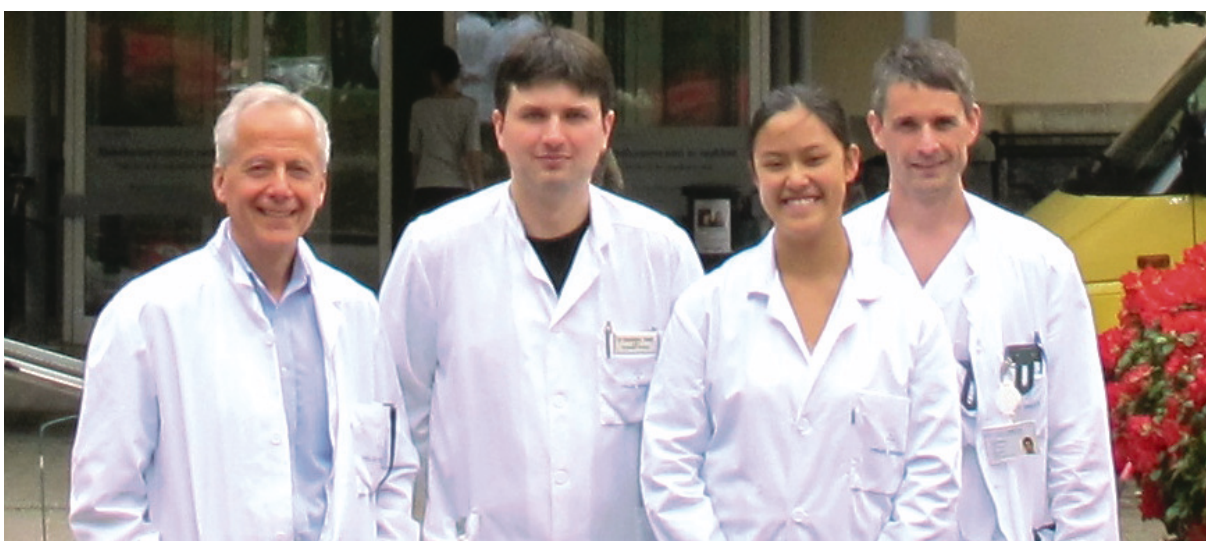

Fra venstre mot høyre: Laurence Bindoff, Charalampos Tzoulis (postdoktor og førsteforfatter), Gia Tuong Tran (forskerlinje, medisinstudent), Kristoffer Haugarvoll (postdoktor). Foto Jon Furlund Owe

\title{
Nevrontap uten parkinsonisme
}

\author{
Mitokondrieskade som følge av en genfeil fører til tap av nerveceller \\ i det samme området av hjernen som rammes ved Parkinsons sykdom, \\ men det gir ikke klinisk parkinsonisme.
}

Degenerasjon av substantia nigra antas å være hovedårsaken til de motoriske symptomene ved Parkinsons sykdom, og mitokondriell dysfunksjon kan gi opphav til degenerasjon og nevrontap i dette området. Norske forskere har nylig undersøkt pasienter med mutasjoner i genet som koder for enzymet polymerase gamma (POLG), som repliserer og reparerer mitokondrielt DNA. Målet var å se hvordan denne mutasjonen påvirker nevronene i substantia nigra (1).

Levende pasienter ble undersøkt med DaTskann og positronemisjonstomografi (PETskann), og hjernevev fra avdøde pasienter med genfeilen ble undersøkt med nevropatologiske teknikker. Alvorlig nevrontap ble funnet i flere hjerneregioner, og substantia nigra var særlig hardt rammet. Til tross for at nevrondegenerasjonen i substantia nigra, vurdert både in vivo og post mortem, var mer uttalt hos POLG-pasienter enn hos Parkinsonpasienter, hadde pasientene med POLGmutasjoner ingen kliniske tegn til parkinsonisme. Resultatene er nylig publisert i det prestisjetunge tidsskriftet Brain.

- Studien bekrefter at nevroner i substantia nigra er svært sårbare for sviktende mitokondriefunksjon, og særlig mitokondriell DNA-skade, sier Laurence Bindoff, som er sisteforfatter av artikkelen.

- At pasientene med POLG-mutasjoner ikke utvikler parkinsonisme, tyder på at det er mulig å kompensere for de motoriske symptomene ved degenerasjon av substantia nigra ved andre tilstander. Kanskje er den samtidige tilstedeværelsen av talamisk og cerebellar dysfunksjon hos disse pasientene med på å oppheve konsekvensene av substantia nigra-degenerasjonen, men det er også sannsynlig at hittil ukjente tilleggsfaktorer spiller en rolle.
- Å forstå mekanismene som forhindrer utvikling av parkinsonisme hos POLGpasientene vil være avgjørende for vår forståelse av patofysiologien ved Parkinsons sykdom. Slik vil vi kunne identifisere nye behandlingsstrategier for denne invalidiserende sykdommen, sier Bindoff.

\section{Mitokondrieforskning}

Studien ble gjennomført ved Nevrologisk avdeling, Haukeland universitetssykehus i samarbeid med Patologisk avdeling, Rettsmedisinsk avdeling og PET-senteret ved samme sykehus samt Klinisk institutt 1, Universitetet i Bergen. Mitokondrieforskningsgruppen ledes av Laurence Bindoff og flere fra gruppen var involvert i arbeidet, bl.a. nevrolog og postdoktor Charalampos Tzoulis, medisinstudent Gia Tuong Tran, postdoktor Kristoffer Haugarvoll og ph.d.student Novin Balafkan. Gruppens hovedinteresse er hvordan mitokondrieforstyrrelser fører til sykdom, og de har publisert flere artikler om POLG-mutasjon. Denne studien omfattet avansert bildediagnostisk kompetanse fra Senter for nukleærmedisin og PET (Thomas Schwarzlmüller, Karsten Specht, Martin Biermann) og nevropatologisk ekspertise fra Avdeling for patologi (Hrvoje Miletic og Peer K. Lilleng).

\section{Hanne Støre Valeur}

hanne.store.valeur@legeforeningen.no Tidsskriftet

\section{Litteratur}

1. Tzoulis C, Tran GT, Schwarzlmüller T et al. Severe nigrostriatal degeneration without clinical parkinsonism in patients with polymerase gamma mutations. Brain 2013; 136: 2393-404
Ordforklaringer

Substantia nigra: Et område i mesencephalon som består av to deler, pars compacta og pars reticulata. Pars compacta inneholder pigmenterte, dopaminerge nevroner som har med kontroll av bevegelser å gjøre.

Polymerase- $\gamma$ (POLG): Et enzym som er lokalisert i mitokondriene og som er viktig for replikasjon og reparasjon av mitokondrie-DNA. Mutasjoner i POLG-genet er forbundet med et vidt spektrum av tilstander, bl.a. epilepsi, ataksi og Alpers' sykdom.

Parkinsons sykdom: En progressiv nevrologisk sykdom som kjennetegnes av tremor, rigiditet og langsomme bevegelser (bradykinesi). Parkinsons sykdom er hyppig, og forekomsten $\emptyset$ ker med økende alder. I de fleste tilfeller er årsaken ukjent (idiopatisk), men det finnes også arvelige former.

DaT-skann: Metode som bruker et radioaktivt stoff (ioflupan ${ }^{123}$ ) og scintigrafi for å visualisere den presynaptiske dopamintransporteren (DAT), særlig i striatum. Slik kan man måle i hvilken grad de dopiminerge nevronforbindelsene er intakte.

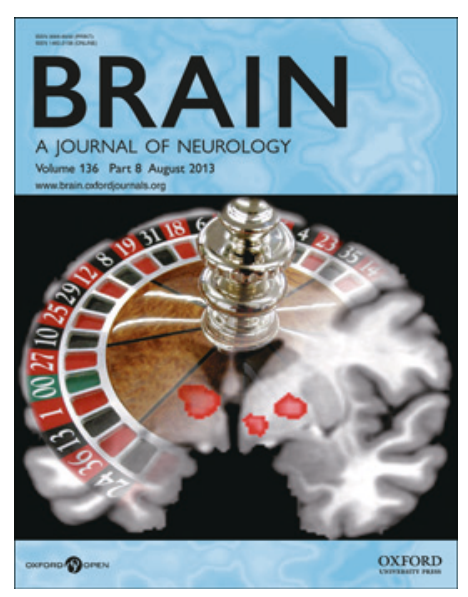

Studien ble e-publisert 26.4. 2013 i det prestisjetunge nevrologiske tidsskriftet Brain 